\title{
試料電解を用いた誘導結合プラズマ発光分析法による 鋼の迅速分析
}

\author{
近藤 裕之 ${ }^{\circledR *}$, 小野 昭紘 ${ }^{*}$, 植 村 健 ${ }^{* *}$, 南 孝 明**
}

Rapid analysis of steel by ICP-AES with electrolytic dissolution

Hiroyuki Kondo, Akihiro Ono*, Takeshi Uemura and Taka-aki Minami**

\footnotetext{
*Nippon Steel Corp., Advanced Technology Research Laboratories, 1618, Ida, Nakahara-ku, Kawasaki-shi, Kanagawa 211

${ }^{* *}$ Horiba, 2, Kisshoin Miyanohigashicho, Minami-ku, Kyoto-shi, Kyoto 601
}

(Received 16 February 1996, Accepted 25 March 1996)

\begin{abstract}
A rapid analytical system for steel samples using ICP-AES has been developed. In this system a steel sample is directly dissolved by electrolysis using a flow-through electrolytic cell, and the solution containing dissolved ions is introduced to plasma continuously. After the sample is set on the electrolysis chamber, an automatic sequence proceeds under the control of a personal computer. A sample can be analyzed in about $60 \mathrm{~s}$. Steel samples of Japanese Standards of Iron and Steel were dissolved with controlled current electrolysis in hydrochloric acid $(1+1)$ as the electrolyte, followed by ICP-AES measurement. The analytical results were in good agreement with the certified values except for titanium in a few samples. In order to determine titanium contained in steel in the form of inclusions, which could be hard to dissolve in acid media at room temperature, the composition of the electrolyte solution and electrolytic potential were studied. By electrolyzing the samples in hydrochloric acid-nitric acid mixture $(1+1+2)$ and maintaining the electrolytic potential at $0.8 \sim 1 \mathrm{~V}(v s . \mathrm{Ag} / \mathrm{AgCl}$ reference electrode), titanium contents which were in good agreement with the certified values could be obtained in all the samples examined in this experiment.
\end{abstract}

Keywords : rapid analysis of steel sample; ICP-AES; electrolytic dissolution; determination of titanium in steel.

\section{1 緒言}

近年, 鉄鋼の高清浄度化が進み, 転炉や二次精錬等の 製鋼工程管理分析においても極めて低含有率の不純物成 分の分析が必要となっている. 現在, 工程管理分析の主 力はスパーク発光分析法であるが, 既に, 実際に生産さ

* 新日本製鐵 (株) 先端技術研究所: 211 神奈川県川崎市 中原区井田 1618

** (株) 堀場製作所理化学開発部: 601 京都府京都市南区 吉祥院宮の東町 2
れる鋼種の分析において, 幾つかの重要な成分の低含有 率域での定量が困難になりつつある1). 又, 鋼種によっ ては特定成分の含有率がその特性や品質を大きく左右す るので, 高品質製品の生産性向上及び品質管理の面か ら,より高精度の迅速分析法が求められている.

スパーク発光分析法に対して, 誘導結合プラズマ発光 分析法 (ICP-AES), 誘導結合プラズマ質量分析法 (ICP-MS), 吸光光度法等の分析法は, 一般に定量感 度, 精度が優れている. しかし, (1)試料を切削粉とす る, (2)これを正確にひょう量し, 酸で分解する, (3)正確 
に一定容量とするなどの煩雑な操作を経るために長時間 を要し, 迅速性が要求される工程管理分析には不適であ った.

このような湿式分析用の試料溶液調製に要する時間を 大幅に短縮するためには，溶鋼から採取したブロック状 鋼試料の迅速分解技術が必要となる。

これまでに，ブロック状金属試料の電解を用いた迅速 ICP-AES に関して幾つかの報告例がある.Yuan らは, $\mathrm{Al}$ 合金中の $\mathrm{Zn}, \mathrm{Si}, \mathrm{Fe}, \mathrm{Mn}, \mathrm{Cr}, \mathrm{Mg}$ 及び $\mathrm{Cu}$ の各 元素を $0.001 \sim 10 \mathrm{mass} \%$ の範囲で相対標準偏差 4\% 以 下の精度で定量した ${ }^{2}$. 鉄鋼試料については, Souza ら が，ステンレス鋼中の $\mathrm{Cr}, \mathrm{Ni}, \mathrm{Mn}, \mathrm{Si}$ 及び $\mathrm{Fe}$ を定量 している3)が，これらは含有率 0.3 mass\% 以上において であり，より微量域については触れていない，又， Flock らが $\mathrm{Al}, \mathrm{Mn}, \mathrm{Ni}, \mathrm{Cr}$ の各元素について, 0.001 30 mass\% の含有率範囲で含有率と発光強度の間 に良好な直線性を見いだしている ${ }^{4)}$ が，定量精度までは 詳しく調べていない。

更に，鋼中には，室温では酸で容易に分解されない析 出物や介在物が含まれている場合がある。これまでの報 告例では, 試料電解には定電流電解法のみが適用されて おり，難分解性化合物を形成した成分を定量するという 観点からの電解条件の検討は行われていない.

本研究では，独自にブロック状鋼試料迅速電解装置を 製作し, ICP-AES と組み合わせた分析システムを形成 した. 本システムを用いて鋼試料の分析を行い, 微量成 分の定量精度及び分析時間短縮の観点から工程管理分析 法としての適用の可能性について, 又, $\mathrm{Ti}$ を例に難分 解性化合物を室温で電解し，定量するための最適電解条 件について検討した.

\section{2 ブロック状鋼試料迅速分解装置の概要}

Fig. 1 に試作装置の概略構成図を示す.

以下，操作手順に沿って各部の機能を説明する.

(1) 試料の設定

研磨した試料表面を下向きに電解セル（8）上に設定 し，空気圧により試料固定用エアーシリンダー（5）を 下降させ試料（6）を固定する．このとき，試料と電解 装置 (1) との電気的導通がとられる.

（2）電解液の送液

定流量ポンプ（ペリスタ型ポンプ）（4）にて一定流量 で電解液を送液し，試料電解セルに導入する。

（3）電解

電解装置により試料を作用電極，セル中に組み込まれ たグラファイト（7）を対極として電解を行う。電位は,

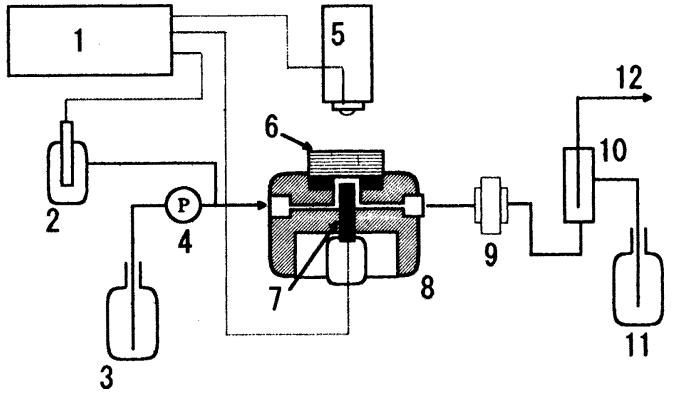

Fig. 1 Schematic diagram of the system for rapid sample decomposition

1: potentio-stat/galvano-stat; 2 : reference electrode; 3: electrolyte container; 4: pump; 5: air cylinder; 6: sample; 7: cell electrode; 8: electrolysis cell; 9: filter; 10: collecting tube; 11: waste; 12: to ICP

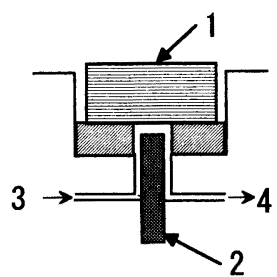

(a)

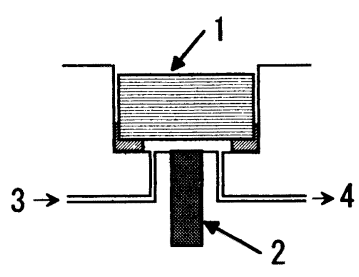

(b)
Fig. 2 Schematic diagram of electrolysis cell (a) After improvement. Electrolyte flowed along a cell electrode sweeping away the gases evolved during electrolysis thus stabilizing the electrolysis. (b) Before improvement. The evolved gases were retained in the electrolysis cell resulting in an electrical isolation. 1: sample; 2 : cell electrode; 3 : electrolyte inlet; 4 : electrolyte outlet

参照電極（2）に対する電位差として測定される.

電解セルはテフロン製ブロックを加工し，内部に電解 液流路を設けて作製した。なお，当初，Fig. 2(b) の構 造としたが，安定した電解制御ができなかった。これ は，七ル内で電解により発生した水素ガスにより絶縁状 態が生じるためと考えられた．このため Fig. 2(a) の構 造に改造したところ上記の問題を解消することができ た. Fig. 2(a) の構造では，流入する電解液は常に対極 と接触した状態でセル内の気泡を掃き出しながら試料表 面に供給されるため各電極間の導通が確保されるものと 考えられる. Fig. 2(a) の電解セルの試料電解面積は直 径 $10 \mathrm{~mm} \phi$, 電極間間げきは $1 \mathrm{~mm}$ で, 内容積は約 
$0.08 \mathrm{ml}$ である.

(4) 測定

試料を電解した溶液は, ラインフィルター（テフロン 製，ポアサイズ $10 \mu \mathrm{m}$ ）（9）によって未分解残留物を取 り除いた後, 電解液貯留管（10）に流入する，管内は, 刻々と新たな電解溶液で置換されるが，これをネブライ ザーにより吸入し, 分析する. 電解液貯留管の液がたま る部分の寸法は, 内径 $5 \mathrm{~mm} \phi \times$ 深さ $25 \mathrm{~mm}$ で, 内容 積約 $0.5 \mathrm{ml}$ とした。

なお, 波長走査型の ICP-AES の場合は, 分析線ごと に測定タイミングが異なることから, 電解液濃度の経時 的変動の影響を避けるため, 一定時間電解し捕集した電 解液を導入し, 分析する方法が適していた.

(5) 洗浄

定流量ポンプにて水を送液し, 電解セル及び配管内を 洗浄する. 配管は, すべてテフロン製チューブ (内径 1 $\mathrm{mm}$, 外径 $2 \mathrm{~mm}$ ) で行い, ジョイント類もすべてテフ ロン製を用いた。

試料設定後, 一連の操作はパーソナルコンピュータに より自動制御されるシステムを開発した。

\section{3 鋼試料の分析}

試料は, 直径約 $30 \mathrm{~mm} \phi$, 高さ $10 \sim 30 \mathrm{~mm}$ の円柱型 鋼試料の一底面を研磨して用いた。

塩酸 $(1+1)$ 又は塩酸+硝酸十水 $(1+1+2)$ の混酸 を電解液とし, これを $5 \mathrm{ml} / \mathrm{min}$ の流量で電解セルに供 給して定電流電解又は定電位電解を行った。温度は, 試 料, 電解液とも室温とした.

ICP-AES は，島津製作所製 GVM-1000P（多元素同 時型; 真空分光器）又は堀場製作所-京都光研製 PS1000 (波長走查型) を用いた. ICP-AES 分析条件を Table 1 に, 各分析線を Table 2 に示す.

標準溶液は純鉄（Johnson-Massay 製，99.99\% Fe） $0.3 \mathrm{~g}$ 又は $0.5 \mathrm{~g}$ を電解液と同一組成の酸溶液 $20 \mathrm{ml}$ で 分解し, 各微量成分元素の原子吸光用標準溶液 (和光純 薬製) を適宜加え, 上記酸溶液で $100 \mathrm{ml}$ に希釈して調 製した。このようにして調製した Fe 濃度の異なる 2 組 の標準溶液の分析から，それぞれの Fe 濃度における検 量線を作成した.これらの検量線を, 電解条件によって 異なる電解液中 Fe 濃度に応じて使い分けた.

\section{4 実験結果と考察}

\section{$4 \cdot 1$ 試料䉓解の再現性}

塩酸 $(1+1)$ を電解液とし $1.5 \mathrm{~A}$ (電流密度 1.9 $\left.\mathrm{A} / \mathrm{cm}^{2}\right)$ で定電流電解を行った際の $\mathrm{Fe}$ 発光強度の経時
Table 1 Operating conditions of ICP-AES

\begin{tabular}{|c|c|c|}
\hline & $\begin{array}{l}\text { Multi- } \\
\text { Channel }\end{array}$ & Sequential \\
\hline $\mathrm{RF}$ power $/ \mathrm{kW}$ & 1.2 & 0.9 \\
\hline Coolant gas flow $/ 1 \mathrm{~min}^{-1}$ & 10.5 & 15 \\
\hline Plasma gas flow $/ 1 \mathrm{~min}^{-1}$ & 1.5 & 0.5 \\
\hline Carrier gas flow $/ 1 \min ^{-1}$ & 1.0 & 0.38 \\
\hline Purge gas flow $/ 1 \mathrm{~min}^{-1}$ & 4.0 & - \\
\hline Integration time/s & 15 & 5 \\
\hline
\end{tabular}

Table 2 Analytical Iines of ICP-AES

\begin{tabular}{lll}
\hline & Multichannel & Sequential \\
\hline $\mathrm{Fe}$ & $259.94 \mathrm{~nm}$ & $438.36 \mathrm{~nm}$ \\
$\mathrm{Si}$ & 251.61 & 251.61 \\
$\mathrm{Mn}$ & 257.61 & 257.61 \\
$\mathrm{Ni}$ & 231.60 & 231.60 \\
$\mathrm{Cu}$ & 327.40 & 327.40 \\
$\mathrm{Al}$ & 396.15 & 396.15 \\
$\mathrm{Ti}$ & 334.94 & 334.94 \\
$\mathrm{Cr}$ & 267.72 & 267.72 \\
\hline
\end{tabular}

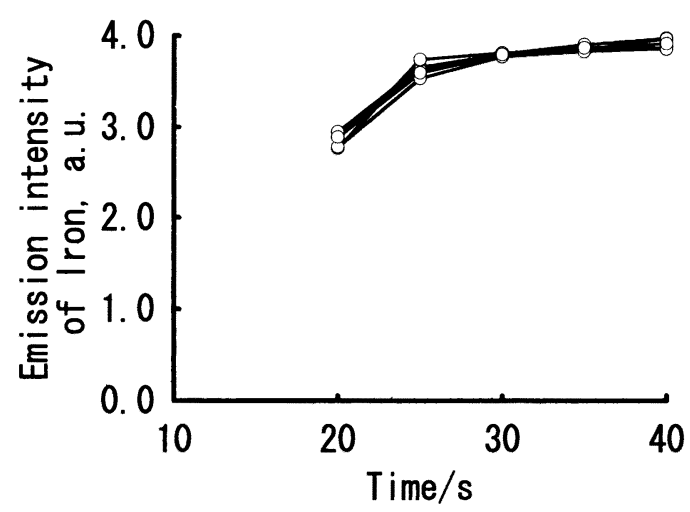

Fig. 3 Response and repeatability of emission intensity of iron in a controlled current electrolysis

変化について, 同一試料を 5 回繰り返し分析した結果 を Fig. 3 に示した. ICP-AES は多元素同時型を用い, 電解と並行して分析を行った.

Fig. 3 に見られるように, $\mathrm{Fe}$ 発光強度は電解開始後, 約 30 秒で安定していることが分かる. 又, この時点に おける $\mathrm{Fe}$ 濃度定量值は平均 $4.96 \mathrm{w} / \mathrm{v} \%$ （相対標準偏差 $1.8 \%)$ で, クーロン量からの計算値によく一致する値 が再現性よく得られた. 同様の結果が $\mathrm{Fe}$ 以外の微量元 素についても得られた。 
Table 3 Analytical results of steel

\begin{tabular}{|c|c|c|c|c|c|c|c|c|}
\hline Sample & & $\mathrm{Si}$ & $\mathrm{Mn}$ & $\mathrm{Ni}$ & $\mathrm{Cu}$ & $\mathrm{Al}$ & $\mathrm{Ti}$ & $\mathrm{Cr}$ \\
\hline \multirow{3}{*}{ JSS162-2 } & Certified V. & 0.50 & 0.098 & 0.31 & 0.042 & 0.015 & - & 0.30 \\
\hline & Found & 0.51 & 0.094 & 0.31 & 0.039 & 0.013 & - & 0.31 \\
\hline & RSD $\%$ & 1.6 & 4.1 & 4.1 & 2.1 & 10.2 & - & 5.8 \\
\hline \multirow[t]{3}{*}{ JSS163-2 } & Gertified V. & 0.21 & 0.57 & 0.11 & 0.10 & 0.026 & - & 0.10 \\
\hline & Found & 0.21 & 0.58 & 0.10 & 0.10 & 0.025 & - & 0.10 \\
\hline & $\mathrm{RSD} \%$ & 1.9 & 2.2 & 1.9 & 3.8 & 4.9 & - & 3.0 \\
\hline \multirow[t]{3}{*}{ JSS168-6 } & Certified V. & 0.21 & 0.41 & 0.015 & - & 0.044 & 0.078 & 0.011 \\
\hline & Found & 0.21 & 0.41 & 0.015 & - & 0.043 & 0.001 & 0.010 \\
\hline & $\mathrm{RSD} \%$ & 1.6 & 1.8 & 1.8 & - & 2.8 & 16.4 & 5.3 \\
\hline Conventional & $\mathrm{HCl}^{1)}$ & 0.22 & 0.42 & 0.016 & - & 0.043 & 0.006 & 0.004 \\
\hline ICP method & $\mathrm{HCl}+\mathrm{HNO}_{3}{ }^{2)}$ & 0.22 & 0.42 & 0.016 & - & 0.046 & 0.077 & 0.010 \\
\hline \multirow[t]{3}{*}{ JSS1003-1 } & Gertified V. & 0.048 & 0.097 & - & - & 0.015 & 0.006 & - \\
\hline & Found & 0.044 & 0.096 & - & - & 0.012 & 0.001 & - \\
\hline & $\mathrm{RSD} \%$ & 1.8 & 1.6 & - & - & 1.9 & 6.6 & - \\
\hline Conventional & $\mathrm{HCl}^{1)}$ & 0.049 & 0.096 & - & - & 0.014 & 0.005 & - \\
\hline ICP method & $\mathrm{HCl}+\mathrm{HNO}_{3}{ }^{2)}$ & 0.049 & 0.094 & - & - & 0.014 & 0.006 & - \\
\hline
\end{tabular}

Electrolysis condition: controlled current electrolysis $\left(1.9 \mathrm{~A} / \mathrm{cm}^{2}\right)$; Electrolyte: $\mathrm{HCl}(1+1)$

1) $\mathrm{HCl}(1+1)$, 2) $\mathrm{HCl}+\mathrm{HNO}_{3}+\mathrm{H}_{2} \mathrm{O}(2+1+3)$

この結果をもとに多元素同時型の ICP-AES を用いた 場合, 電解開始 30 秒後から 15 秒間の発光強度を積算 した. 分析所要時間は, 電解セルや流路の洗浄を含め て，試料を設定してから約 60 秒であった.

\section{$4 \cdot 2$ 分析結果}

Table 3 に日本鉄鋼協会認証標準物質（JSS）の分析 結果を示した.

電解条件は, 塩酸 $(1+1)$ を電解液とし, 流量 5 $\mathrm{ml} / \mathrm{min}, 1.5 \mathrm{~A}$ (電流密度 $1.9 \mathrm{~A} / \mathrm{cm}^{2}$ ) で定電流電解を 行った.

Table 3 に見られるように各成分の認証值との一致は おおむね良好であった，又，繰り返し再現性も，高含有 率域で一部やや相対標準偏差の大きな成分があるもの の,これらを除けば，特に低含有率においては従来の手 操作による ICP-AES による分析と同等の精度が得られ た.

又, Table 3 には示していないが, $\mathrm{Si}$ 含有率が 3 mass\% と高い場合でも他の金属元素と同時に支障なく 分析できた。一例として, 重量法による Si 定量值が 3.17 mass \% の試料が本分析法では， 3.22 mass\% (相対 標準偏差 $1.8 \%$ ）とよく一致する值が得られた。このよ うに高い含有率の $\mathrm{Si}$ を含む試料を酸分解すると加水分 解して析出するため, そのまま ICP-AES 分析を行え ず，残留物処理，あるいは別途重量法による分析を行う 必要があった. 本分析システムでは塩酸による室温での
電解を用いているために Si 成分の析出が起こらなかっ たものと考えられる.

一方, Table 3 中の Ti 定量値を見ると, JSS1003-1 と JSS168-6 については認証值に対し著しく低值を示し ている．これは，Ti を含む析出物が上記電解条件では， 分解されなかったためと考えられる。これらの試料につ いては, ブロック試料から切削粉を採取し, 塩酸 $(1+1)$ 及び塩酸十硝酸十水 $(1+1+2)$ により分解して 調製した試料溶液の ICP-AES 分析も行った。

Table 3 には, その結果を併記した. これらの分析値 の比較からもこれら試料中の $\mathrm{Ti}$ は塩酸 $(1+1)$ では, 室温及び加熱条件下でも完全に分解されない TiC ある いは TiN 等の化合物として存在しているものと考えら れる.

本分析法は, 基本的にいわゆる酸可溶性成分のみを分 析対象とするものである. しかし，鋼中に含まれる析出 物や介在物のなかには上述のように酸組成や加熱条件に よっては酸可溶性成分として取り扱うことができるもの がある. 室温での電気分解による迅速試料分解を特徴と する本分析法において, このような難分解性の化合物を 形成する成分をも定量する可能性について以下に検討し た。

\section{$4 \cdot 3$ 奄解液組成及び電解奄位の検討}

上述の定電流電解では, 試料電位は約 $0.2 \mathrm{~V}$ ( vs. $\mathrm{Ag} / \mathrm{AgCl}$ 参照電極) であった. 試料中の析出物や介在 


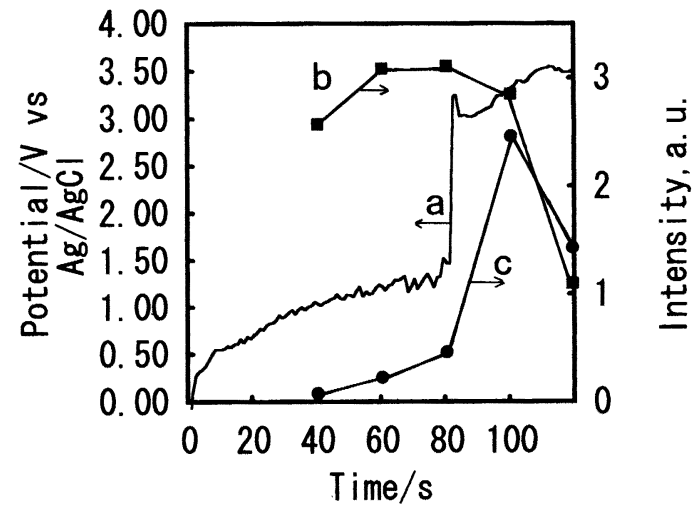

Fig. 4 Sample potential and emission intensities of iron and titanium in controlled current electrolysis a: electrolytic potential of the sample; b: emission intensity of iron; $\mathrm{c}$ : emission intensity of titanium; Electrolyte: $\mathrm{HNO}_{3}+\mathrm{HCl}+\mathrm{H}_{2} \mathrm{O}(1+1+2)$; Sample: JSS168-6

物の分解は, 電解電位及び電解液組成に影響される.

まず，電解液を塩酸十硝酸十水 $(1+1+2)$ の混酸に 変えて定電流電解を行った.このときの試料電位（vs. $\mathrm{Ag} / \mathrm{AgCl}$ 参照電極) と $\mathrm{Fe}$ 及び $\mathrm{Ti}$ の発光強度の経時変 化を Fig. 4 に示した. この図に見られるように，電解 中に試料電位は約 $1.5 \mathrm{~V}$ から $3 \mathrm{~V}$ 付近に上昇し,これ を境に $\mathrm{Ti}$ 発光強度が一時的に増加し, $\mathrm{Fe}$ 発光強度は 減少した。この電位の急上昇は, 硝酸を含む電解液中で 試料表面が不動態化したためと考えられ，試料表面に未 分解のまま残っていた Ti 化合物が電位の上昇とともに

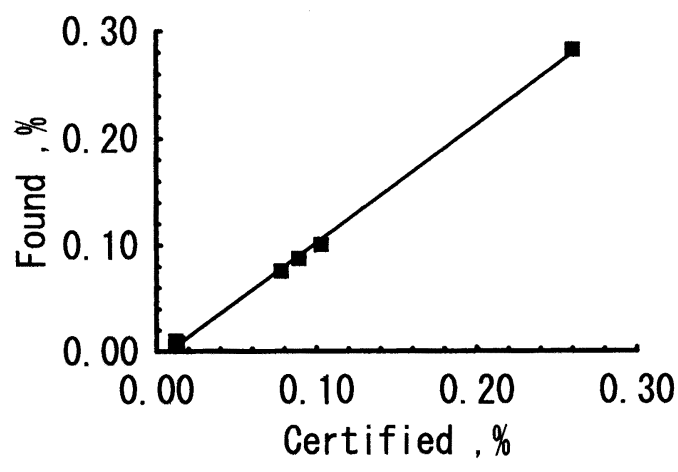

Fig. 5 Determination of titanium in steel samples with the electrolytic dissolution using controlled potential electrolysis

Electrolyte: $\mathrm{HNO}_{3}+\mathrm{HCl}+\mathrm{H}_{2} \mathrm{O}(1+1+2)$; Controlled potential of sample: $1 \mathrm{~V}$

瞬間的に電解されたものと推察される. しかし, 表面が 不動態化した後は, 試料の電解そのものが停止してしま うため各成分の正確な定量は困難であった。この実験結 果から電解電位を適正值に制御する必要があると考えら れた。

次に, 塩酸 $(1+1)$ 及び塩酸+硝酸十水 $(1+1+2)$ のそれぞれを電解液として電位を変えて定電位電解を行 いICP-AES 分析を行った. 試料は, JSS165〜170を用 いた。この実験では，波長走查型 ICP-AES を用い，一 定時間電解して捕集した電解液を ICP-AES へ導入し, 分析した.

Ti 定量結果を Table 4 に示した.

Table 4 Determination of titanium in steel utilizing a controlled potential electrolysis ${ }^{\dagger}$

(Ti, mass \%)

\begin{tabular}{|c|c|c|c|c|c|c|}
\hline \multirow{2}{*}{$\begin{array}{c}\text { Electrolytic } \\
\text { potential } \\
(\mathrm{V} v s . \mathrm{Ag} / \mathrm{AgCl})\end{array}$} & \multicolumn{6}{|c|}{ JSS Sample No./(Certified value) } \\
\hline & $\begin{array}{c}165-2 \\
(0.013)\end{array}$ & $\begin{array}{c}166-2 \\
(0.089)\end{array}$ & $\begin{array}{l}167-2 \\
(0.26)\end{array}$ & $\begin{array}{c}168-6 \\
(0.078)\end{array}$ & $\begin{array}{c}169-6 \\
(0.012)\end{array}$ & $\begin{array}{l}170-6 \\
(0.103)\end{array}$ \\
\hline \multirow{2}{*}{0.1} & 0.004 & 0.080 & 0.29 & 0.010 & 0.002 & 0.002 \\
\hline & - & - & - & - & - & - \\
\hline \multirow{2}{*}{0.5} & 0.006 & 0.085 & 0.29 & 0.069 & 0.009 & 0.079 \\
\hline & 0.005 & 0.083 & 0.30 & 0.064 & 0.002 & 0.034 \\
\hline \multirow{2}{*}{0.8} & 0.009 & 0.087 & 0.28 & 0.070 & 0.010 & 0.087 \\
\hline & 0.010 & 0.089 & 0.29 & 0.072 & 0.011 & 0.104 \\
\hline \multirow{2}{*}{1.0} & 一 & - & - & - & - & - \\
\hline & 0.008 & 0.088 & 0.28 & 0.076 & 0.010 & 0.101 \\
\hline
\end{tabular}

$\dagger$ Upper and lower values for each electrolytic potential were obtained with electrolyte consisting of $\mathrm{HCl}(1+1)$ and $\mathrm{HCl}+\mathrm{HNO}_{3}+\mathrm{H}_{2} \mathrm{O}(1+1+2)$, respectively. 
この結果にも示されているように，電解電位が $0.5 \mathrm{~V}$ 以下では, 試料により低值を与えた。しかし, 電解電位 を上昇させるに伴い低値を示していた試料の $\mathrm{Ti}$ 定量值 も認証值に近づき，いずれの電解液の場合でも $0.8 \sim 1$ $\mathrm{V}$ で各試料ともほぼ満足のいく定量値を得ることがで きた. しかし, 電解液の比較で見ると, 電解電位 $0.8 \mathrm{~V}$ において塩酸のみ及び硝酸を含む混酸の各場合につい て，認証値に対する相対誤差の平均値は，それぞれ $13.9 \%$ 及び $8.6 \%$ であった。このことから, 塩酸のみ より硝酸を含む混酸を電解液としたほうが, Ti を含む 化合物のより完全な分解が進むものと思われる．定量値 と認証值との間の相関係数は, 塩酸十硝酸十水 $(1+1+2)$ の混酸を電解液とした電解電位 $1 \mathrm{~V}$ の条件 において 0.9986 と最も良好であった（Fig. 5).

以上のように，本分析システムにおいて，Ti のよう に難分解性の化合物として試料中に存在する可能性のあ る元素についても電解液組成や電解電位を適宜選択する ことにより分析可能であることが示された，一方， Ti や $\mathrm{Al}$ などが酸化物として試料中に含まれる場合, これ
ら酸化物を電解し分析する可能性については, 今後更に 検討する必要がある．このような点に留意して，鋼種や 目的に応じて電解条件を選択することにより，本分析シ ステムは，普通鋼を中心に幅広い鋼種に適用できるもの と考えられる.

分析処理時間は, 1 分前後であり製鋼プロセスの工程 管理分析に適用可能な迅速さを実現した，又，日常的に 多数の試料分析を行う品質管理分析においても，大幅な 省力化に寄与することが期待できる.

$(1994$ 年 10 月及び 1995 年 11 月, 日本鉄鋼協会第 $)$ （128 回及び 130 回秋季講演大会において一部発表）

\section{文献}

1）小野昭紘: 鉄と鋼, 77, 1809 (1991).

2) D. Yuan, X. Wang, P. Yang, B. Huang: Anal. Chim. Acta, 251, 187 (1991).

3) I. G. Souza, H. Bergamin F., F. J. Krug, J. A. Nobrega, P. V. Oliveira, B. F. Reis, M. F. Gine: Anal. Chim. Acta, 245, 211 (1991).

4) J. Flock, K. Ohls: Fresenius' Z. Anal. Chem., 331, 408 (1988).

\section{要 旨}

電解液を一定流量で送夜しながらブロック状鋼試料を電解し電解液を ICP 発光分析装置のプラズマ へ導入することにより，迅速に分析するシステムを開発した．試料設定後，一連の操作をパーソナルコ ンピュータにより自動制御した．分析所要時間は 1 武料当たり約 60 秒であった．本システムを用いて 鉄鋼認証標準物質を分析した。試料中に炭化物や窒化物等の難分解性化合物として存在する可能性のあ るチタンを定量するために，最適な電解液組成や電解電位について検討した．塩酸十硝酸十水 $(1+1+2)$ の混酸を電解液とし，0.8 $1 \mathrm{~V}(v \mathrm{~s} . \mathrm{Ag} / \mathrm{AgCl}$ 参照電極）で定電位電解することにより，低 合金鋼の各試料中のチタンについても他の微量共存成分とともにほぼ認証値と一致する定量值を得た. 又, 高含有率のケイ素（約 3 mass\%）も加水分解による析出が起こらず他の成分と同時に定量可能で あった。 